\title{
Floodwater storage capacity of the Middle Daugava floodplain
}

\author{
Dāvis Gruberts, Kristīne Vilcāne \\ Daugavpils University
}

\begin{abstract}
This study highlights the flood risk prevention services provided by the Middle Daugava river-floodplain system located downstream from Daugavpils City. Today, it acts as a principal storage area for floodwaters of the Daugava River during the spring floods, therefore diminishing the risk of flooding and related costs for urban municipalities like Jēkabpils and Pḷavinas located further downstream. Statistical analysis of hydrological data records of the Daugava River at Daugavpils and Jēkabpils during the top-10 flood events in $20^{\text {th }}$ century are performed in order to quantify the largest daily discharge deficits between these two hydrological posts as well as to calculate the amount of floodwaters that could be intercepted by the entire floodplain area. The highest daily discharge deficit $\left(2230 \mathrm{~m}^{3} \mathrm{~s}^{-1}\right)$ is used to calculate additional water level heights for Jēkabpils town if the floodplain did not intercept the floodwaters at all. Therefore, reduction of annual flood risk level provided by the existing riverfloodplain system of the Middle Daugava River could be assessed from hydrological perspective as well as from the Ecosystem Services Concept point of view.
\end{abstract}

Keywords: Daugava River, Ecosystem Services Concept, flod risk prevention, floodplain storage capacity.

\section{INTRODUCTION}

The river-floodplain system of the Middle Daugava is located in South-East Latvia, within the EastLatvian Lowland, downstream from Daugavpils City (Fig. 1). In this stretch, the Daugava's valley is shallow and wide, with broad segments of floodplains located on its both sides behind natural levees [2]. Its hydrological regime is still unaffected by the largescale hydro-engineering projects and modifications. During the spring floods, this river-floodplain system acts as principal storage area for the floodwaters of the Daugava River that are intercepted and stored there for several weeks [4].

Usually, this floodplain area is inundated from late March till mid-May [1], depending on the peak flood discharge of the Daugava River at Daugavpils and the amount of discharge produced by snowmelt and rainfall in local drainage network.

The floodwater storage capacity of the Middle Daugava river-floodplain system has been assessed for the first within the scope of National Research Program "KALME" in 2007 [4]. According to digital elevation model of this area created by geomatic methods, the floodwater storage capacity of the Middle Daugava river-floodplain system exceeds 0.31 $\mathrm{km}^{3}$ at mean floodwater level. In addition, it is capable to intercept at least $4.0610^{7} \mathrm{~m}^{3}$ of the Daugava's floodwaters per day as estimated for the record spring floods in April-May, 1931 [4].

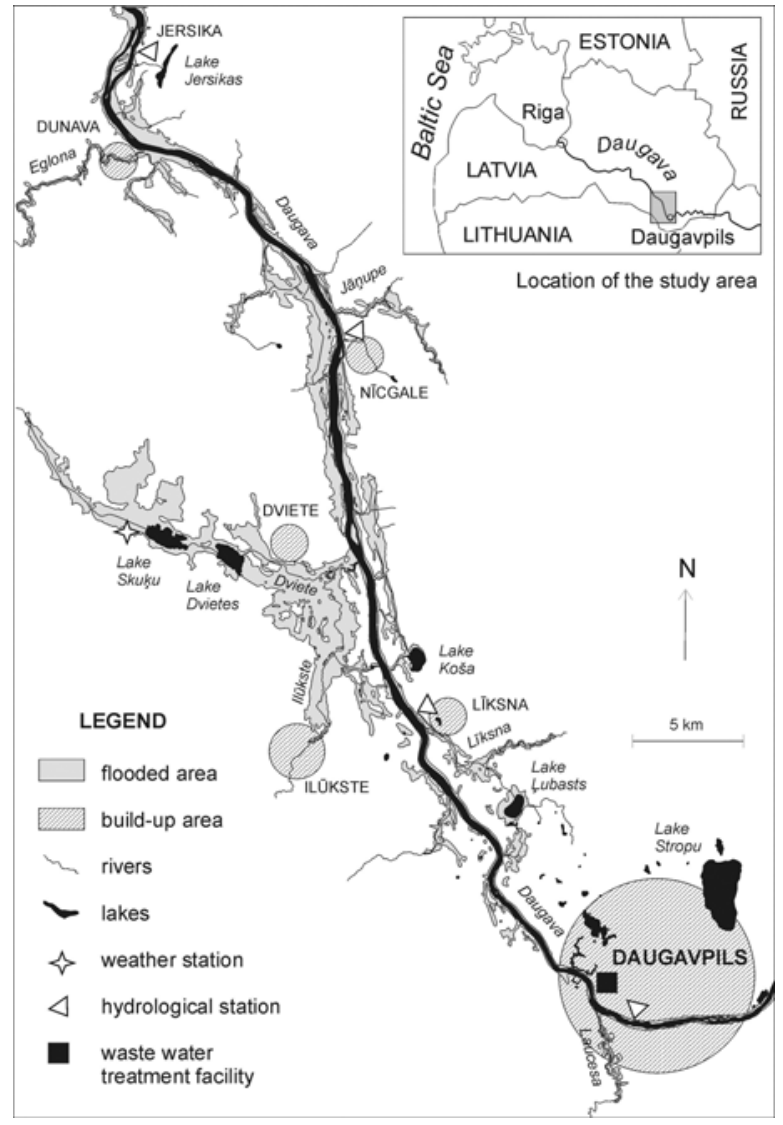

Fig. 1. The river-floodplain system of the Middle Daugava between Daugavpils and Jersika 
These estimations are based on an assumption that negative differences between the daily discharge values (i.e. the discharge deficits) stated between the Daugavpils and Jēkabpils hydrological posts indicate the effect of floodwater detention (interception) by the floodplain area at the beginning of its filling phase [4].

Therefore, reduction of annual flood risk level provided by the river-floodplain system of the Middle Daugava could be assessed from hydrological perspective as well as from the Ecosystem Services Concept point of view [3].

Until now, the effect of the floodwater detention by the Middle Daugava's river-floodplain system has been assessed for the above mentioned record spring floods in 1931 only. Similar cases, when the daily discharge values were much lower at Jēkabpils than at Daugavpils could be detected for other years too [4].

The aim of this study is to assess the maximum floodwater storage capacity of this river-floodplain system during the floods based on the analysis of hydrological data records of the Top-10 flood events of the $20^{\text {th }}$ century. This study is aimed also to highlight the flood risk reduction services provided by the existing river-floodplain system of the Middle Daugava for Jēkabpils municipality located further downstream.

\section{METHODS}

For this study, the top-10 spring flood events of the $20^{\text {th }}$ century were selected by taking into account the peak flood discharges of the Daugava River at Daugavpils [12]. The recorded daily discharge values at Daugavpils and Jēkabpils were obtained for the selected years from the historic annual publications of hydrological observations on Latvia's rivers and lakes [6-11]. For those years when the discharge records at Jēkabpils were missing, their values were obtained from the stage-discharge relationship curve constructed for the record floods in 1931 (Fig. 2).

Differences in the daily discharge values between both hydrological posts were calculated for each date in March, April and May directly as well as by taking into account a delay in 24 hours which is needed for the floodwaters to travel approximately $100 \mathrm{~km}$ long distance between these two hydrological posts [2]. Negative differences (the discharge deficits) were attributed to the floodwater detention effect by the floodplain and used for further analysis. To assess the maximum floodwater storage capacity of the riverfloodplain system of the Middle Daugava between Daugavpils and Jēkabpils during its filling phase, the daily discharge deficit values were summed-up. Finally, additional increase of the floodwater level at Jëkabpils was assessed for the highest amount of daily discharge intercepted by the floodplain by means of the stage-discharge relationship curve (Fig. 2).

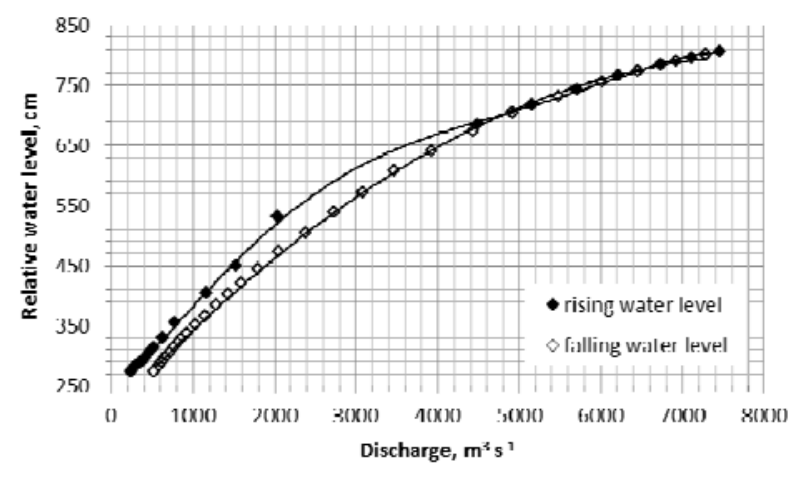

Fig. 2. Stage-discharge relationship curve for the Daugava River at Jèkabpils during the record spring floods in 1931

\section{RESULTS AND DISCUSSION}

During the entire history of regular hydrological observations on the Daugava River at Daugavpils, there were 14 significant flood events when the peak flood discharge reached and/or exceeded $4000 \mathrm{~m}^{3} \mathrm{~s}^{-1}$ (Fig. 3). The top-10 floods of the $20^{\text {th }}$ century are those observed in 1922, 1924, 1929, 1931, 1941, $1951,1953,1956,1958$, and 1962, respectively.

When the daily discharge values at Daugavpils and Jēkabpils are compared to each other, significant negative differences could be detected for the first days of the water level rise phase (Table 1). However, the daily discharge values recorded at Jêkabpils were also compared to those recorded at Daugavpils a day before due to the above mentioned delay period ( 24 hours) for the passage of the floodwaters from Daugavpils to Jēkabpils. In result, the recalculated discharge deficits are much lower but, nevertheless, quite impressive (Table 1).

Comparison of the recalculated discharge deficits at different years shows that the magnitude of the floods is not the single most important factor that determines the amount of floodwaters that is intercepted by the Middle Daugava's floodplain on a single day.

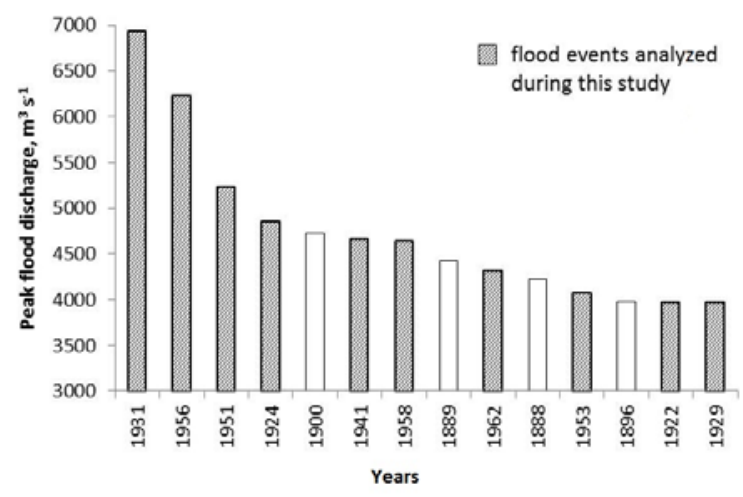

Fig. 3. The largest flood events on the Daugava River at Daugavpils since 1881. (The analyzed flood events are presented in descending order according to their peak discharges. White bars represent other major flood events that were not analyzed during this study. Their discharges are presented here for comparison only) 
TABLE 1

DisCHARGE DEFICITS FOR THE MidDLE DAUGAVA RIVER BETWEEN DAUGAVPILS AND JĒKABPILS HYDROLOGICAL POSTS DURING THE TOP-10 SPRING FOOD EVENTS OF THE $20^{\text {TH }}$ CENTURY

\begin{tabular}{|l|l|l|l|}
\hline Year & $\begin{array}{l}\text { The peak flood discharge at Daugavpils, } \\
\mathrm{m}^{3} \mathrm{~s}^{-1}\end{array}$ & $\begin{array}{l}\text { Largest daily discharge deficits when no } \\
\text { time delay is applied, } \mathrm{m}^{3} \mathrm{~s}^{-1}\end{array}$ & $\begin{array}{l}\text { Largest daily discharge deficits } \\
\text { when the 24-hours delay period is } \\
\text { applied, } \mathrm{m}^{3} \mathrm{~s}^{-1}\end{array}$ \\
\hline 1931 & 6930 & -1550 & -470 \\
\hline 1956 & 6230 & -2560 & -800 \\
\hline 1951 & 5230 & -630 & -290 \\
\hline 1924 & 4850 & -2270 & -2230 \\
\hline 1941 & 4660 & -1410 & -800 \\
\hline 1958 & 4640 & -720 & -450 \\
\hline 1962 & 4320 & -610 & -360 \\
\hline 1953 & 4070 & -140 & -240 \\
\hline 1922 & 3970 & +880 (no deficit recorded) & +740 (no deficit recorded) \\
\hline 1929 & 3970 & -139 & -51 \\
\hline
\end{tabular}

For example, the record-high spring floods in 1931 has relatively low discharge deficit value $\left(470 \mathrm{~m}^{3} \mathrm{~s}^{-1}\right)$, while in 1924 it exceeds $2200 \mathrm{~m}^{3} \mathrm{~s}^{-1}$ at much lower peak discharge (Table 1). Such differences could be explained by several factors.

The first driving factor is progression of the snowmelt front across the Daugava's basin at spring. The snowmelt that produces annual floodwaters usually starts in the lower (western) part of the Daugava's basin, and its front moves to the upper (eastern) part of the basin a few days/weeks later. Therefore, local drainage area along the Middle Daugava produces its own minor flood pulse at first, which however moves away quickly, in a matter of days. Under such circumstances, the major flood pulse from the Upper Daugava meets almost no resistance from local drainage network when it reaches the Middle Daugava's floodplain area at Daugavpils. Therefore, under 'normal' snowmelt front progression scenarios (i.e. from West to East) the floodplain area of the Middle Daugava has maximum storage capacity. In addition, floodwater detention by the floodplain is significantly enhanced by formation of the ice jams within the Daugava's channel at Lîksna village, Glaudānu Island and other sites [14]. During the extreme ice jams, the floodplain area of the Middle Daugava transports up to $70 \%$ of total floodwater discharge [5].

In contrast, the most significant flood events in 1931 and 1956 were produced by unusual snowmelt scenarios - the snowmelt started simultaneously within the entire drainage basin of the Daugava River. In addition, the amount of snow that accumulated during winter season was exceptional (up to 200 and $250 \%$, respectively) [13]. Simultaneous melting of the snow cover within the entire drainage basin produced also large local flood pulses which prevented massive intrusion of the Daugava's floodwaters into the floodplain area. Therefore, the maximum discharge deficits in 1931 and 1956 were much lower than that recorded for April 1924.

Therefore, the largest floodwater detention effect of the Middle Daugava floodplain could be observed in those years when hydrological role of locally generated snowmelt runoff is less important.

In this pilot-study, the largest daily discharge deficit $\left(2230 \mathrm{~m}^{3} \mathrm{~s}^{-1}\right.$ or $1.9610^{8} \mathrm{~m}^{3}$ per day) was detected for April 4, 1924. The sum of negative differences over a five days period (April 3-7, 1924) reached $6.1810^{8} \mathrm{~m}^{3}$ or $0.62 \mathrm{~km}^{3}$ (Fig. 4). It is comparable to the floodwater storage capacity at mean floodwater level $\left(0.31 \mathrm{~km}^{3}\right)$ estimated from digital elevation model [4]. Obviously, the floodwater storage capacity of the entire Middle Daugava's floodplain area is much larger at record high floods.

The discharge deficit in $2230 \mathrm{~m}^{3} \mathrm{~s}^{-1}$ means also reduction of the floodwater level stage at Jēkabpils by 1-3 m (Fig. 2.). In other words, if the floodplain did not intercept the floodwaters at all, there would be about 1-3 meters higher water level during the floods depending on the peak flood discharge characteristics.

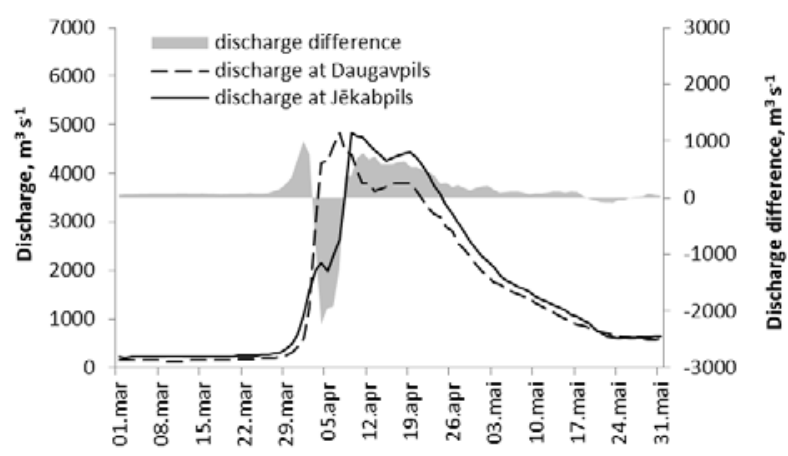

Fig. 4. Daily discharges of the Daugava River at Daugavpils and Jēkabpils and their differences during the spring floods in 1924 [6] The differences in discharges are calculated by taking into account the 24 hours delay period 
Furthermore, the maximum floodwater capacity of the Middle Daugava's floodplain (i.e. $0.62 \mathrm{~km}^{3}$ ) significantly exceeds total water storage capacity of the Plavinu reservoir $\left(0.51 \mathrm{~km}^{3}\right)$ - the largest artificial reservoir in Latvia that is used for electricity generation. Thus, the natural floodplain area located between Daugavpils and Jēkabpils cities has much larger regulating effect on the discharge characteristics of the Daugava River during the floods than that generated by operation of the Pḷavinu hydroelectric power station's dam at Aizkraukle.

These two facts clearly indicate that the flood risk prevention services provided by this natural lowland river-floodplain system in South-East Latvia are of regional as well as of national importance in the context of the Ecosystem Services Concept [3] as well as the European Union's Floods Directive.

In fact, the above mentioned maximum floodwater capacity for this river-floodplain system was rather underestimated. Even the largest daily discharge deficits obtained during the historic hydrological data analysis and comparison are masked by additional runoffs generated by several small tributaries (Dubna, Laucesa, Līksna, Berezovka, etc.). Evaporation from the floodplain's water surface should be also taken into account. Therefore, it is right to assume that, under favorable conditions, the maximum amount of floodwaters that could be intercepted by the entire floodplain area of the Middle Daugava River between Daugavpils and Jēkabpils certainly exceeds those 0.6 $\mathrm{km}^{3}$ stated for the spring floods in 1024 .

\section{CONCLUSIONS}

Under favorable conditions, the Middle Daugava's floodplain area located between Daugavpils and Jēkabpils cities is capable to absorb at least $2230 \mathrm{~m}^{3}$ of floodwaters per second, and accumulate more than $0.2 \mathrm{~km}^{3}$ of them on a single day during the filling phase of the spring floods. The maximum floodwater storage capacity of the Middle Daugava's floodplain exceeds $0.6 \mathrm{~km}^{3}$, therefore generating strong regulating effect on the Daugava's discharge characteristics.

For towns that are located further downstream it provides significant flood risk reduction service, especially for Jēkabpils municipality. Because of this service, the highest floodwater levels could be reduced by 1-3 meters depending on the peak flood discharge therefore also reducing possible costs related to the flooding effects and flood risk prevention measures at Jēkabpils.

\section{$\mathrm{V}$ ACKNOWLEDGEMENTS}

The authors would like to cordially thank Dr. Elga Apsīte (University of Latvia) and Ing. Rūdolfs Gruberts (Joint-Stock Company "Ceļuprojekts") for their help to obtain the necessary hydrological data records.

\section{REFERENCES}

[1] D. Gruberts, "The four largest floodplain lakes in Latvia: hydrology, hydrochemistry and hydrobiology". In: A. Järvet and E. Lode, Eds., Ecohydrological Processes in Northern Wetlands. Selected Papers of International Conference and Educational Workshop. Tallinn: Tartu University Press, pp. 196-202, 2003.

[2] D. Gruberts and J. Paidere, "Lagrangian drift experiment on the Middle Daugava River (Latvia) during the filling phase of the spring floods." Fundam. Appl. Limnol. Vol. 184 (3): pp. 211230, 2014.

[3] Millennium Ecosystem Assessment. Ecosystems and Human Well-Being: Synthesis. Washington: Island Press, 2005, pp. 155.

[4] A. Škute, D. Gruberts, J. Soms and J. Paidere, "Ecological and hydrological functions of the biggest natural floodplain in Latvia." Ecohydrology \& Hydrobiology, Vol. 8 (2-4), pp. 291306, 2008.

[5] Л. И. Глазачева, Ледовый и термический режим рек озер Латвийской ССР. Рига: Звайгзне, 1965, 217 с.

[6] Гидрологические сведения по рекам и озерам Латвийской ССР. Ленинград: Гидрометеоиздат, 1941.

[7] Гидрологический ежегодник 1951. Том 1. Бассейн Балтийского моря. Выпуск 4-6. Ленинград: Гидрометеоиздат, 1957.

[8] Гидрологический ежегодник 1953. Том 1. Бассейн Балтийского моря. Выпуск 4-6. Ленинград: Гидрометеоиздат, 1958.

[9] Гидрологический ежегодник 1956. Том 1. Бассейн Балтийского моря. Выпуск 4-6. Ленинград: Гидрометеоиздат, 1960.

[10] Гидрологический ежегодник 1958. Том 1. Бассейн Балтийского моря. Выпуск 4-6. Ленинград: Гидрометеоиздат, 1962.

[11] Гидрологический ежегодник 1962. Том 1. Бассейн реки Западная Двина и рек между бассейнами Западная Двина и Неман. Выпуск 4. Ленинград: Гидрометеоиздат, 1964.

[12] Государственный водный кадастр. Том Х. Латвийская ССР. Многолетние данные о режиме $u$ ресурсах поверхносных вод суши. Ленинград: Гидрометеоиздат, с. 23244, 1987.

[13] Р. А. Нежиховский, Наводнения на реках и озерах. Ленинград: Гидрометеоиздат, 1988, с. 184.

[14] А. А. Пасторс, „Зажоры и заторы льда на р. Даугаве на участке г. Екабпилс - г. Плявиняс." Сборник работ Гидрометеорологического чентра. Выпуск 1(21). Ленинград: Гидрометеоиздат, с. 107-120, 1987. 